\title{
SCIDoc

\section{Development and Application Of Edible Film With Bioactive Compound}

Matche S Rajeshwar ${ }^{1 *}$, Chandrababu Anokhi ${ }^{2}$

${ }^{1}$ Department of food packaging technology, CSIR-Central Food Technological Research Institute, Mysuru, India.

${ }^{2}$ School of Ocean Studies, Kerala University of Fisheries and Ocean Studies, Kochi, India.

\section{Abstract}

Edible films were prepared from a mixture of carrageenan, guar gum and glycerol. Lemongrass essential oil (LGO) was added to edible films as bioactive compound. Edible film without essential oil and with different concentrations of essential oil $(0.2 \%$, $0.4 \%, 0.6 \%$ ) were made and their mechanical and barrier properties were evaluated. Thickness ranged from $0.0472 \pm 0.003 \mathrm{~mm}$ to $0.0487 \pm 0.004 \mathrm{~mm}$. The percent elongation decreased up to $20 \%$ when the concentration of essential oil increased. The low WVTR and OTR values were maintained over a range of essential oil concentration of $0.4 \%$ and $0.6 \%$ in the edible film. The minimum WVTR and OTR obtained was $4.04 \pm 3.2 \mathrm{~g} / \mathrm{m}^{2} /$ day and $2.74 \pm 4.0 \mathrm{cc} / \mathrm{m}^{2} /$ day with the incorporation of $0.6 \%$ essential oil in edible film. SEM micrographs and DSC graphs of edible films were affected by the amount of the essential oil incorporated. The FTIR shows the structural interactions of essential oils with the carrageenan material. The developed edible films were applied on lemon fruits and were wrapped without and with different concentrations $(0.2 \%, 0.4 \%, 0.6 \%)$ of lemongrass essential oil incorporated edible films and lemons without edible wrap also kept as a control for comparable studies. The shelf life of lemon wrapped with edible film had longer shelf-life when compared to lemon without edible wrap.

Keywords: Active Packaging; Applications; Bioactive Compounds; Biodegradable Film; Edible Films; Fruits.

\section{Introduction}

Packaging material are separated in to two groups: synthetic and natural. Synthetic packaging is usually petrochemical based and although they are effective in preserving the product and mostly preferred in the industry, it is recommended that the usage of these packaging should be reduced due to environmental pollution and migrationproblems [30]. Edible packaging that obtained from natural resources, have been offered as alternative to those packaging, and can be used in different foods such as fruits and vegetables, dried nuts, meat and meat products, cereal, and dairy products [17]. Fruits and vegetables may decay quickly as the water content of those products are high leading to respiration and transpiration. Thus, the packaging of those is important. Edible films are defined as a thin layer of material which can be consumed and provides a barrier to moisture, oxygen and solute movement for the food [2]. The material can be a complete food coating or can be disposed as a continuous layer between food components.
The main advantage of edible films over traditional synthetics is that they can be consumed with the packaged products. There is no package to dispose even if the films are not consumed, they could still contribute to the reduction of environmental pollution. The films are produced exclusively from renewable, edible ingredients and therefore are anticipated to degrade more readily than polymeric materials. In addition to environmental protection and human health point of view, edible films offer protection to the foods once main packaging is removed. Although there are numerous studies on edible films; there were no studies based on the direct incorporation of the bioactive compound without encapsulation in to film making solution $[8,11,12]$.

\section{Materials and Methods}

\section{Time and Place}

The study was conducted from November to March in Depart-

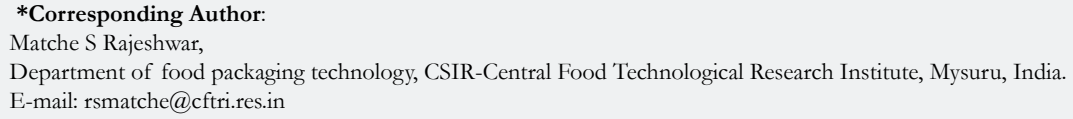

Citation: Matche S Rajeshwar, Chandrababu Anokhi. Development and Application Of Edible Film With Bioactive Compound. Int J Food Sci Nutr Diet. 2021;10(03):524-531. doi: http://dx.doi.org/10.19070/2326-3350-2100091

Copyright: Matche S Rajeshwar ${ }^{\circ} 2021$. This is an open-access article distributed under the terms of the Creative Commons Attribution License, which permits unrestricted use, distribution and reproduction in any medium, provided the original author and source are credited. 
ment of Food Packaging and Technology at CSIR-Central Food Technological Research Institute, Mysore, India.

\section{Research Material}

The chemical reagents used in making of Edible film were I-carrageenan powder (Marine Hydrocolloids company, Kerala), Glycerol (S D Fine Chemical Ltd, Mumbai), Guar gum (High Media Laboratory, Mumbai) and Bioactive compound - Lemongrass essential oil Spice rich seasonings, Kerala.

The instruments used in making and analysing of edible film were Weighing balance, Magnetic stirrer and hot plate (IKA C-MAG), IR Drying chamber, Electronic micrometre (Messmer Instru- ments Ltd, England), Universal Texture Measuring instrument (Lloyd instruments Ltd, England), Scanning Electron Microscopy, Fourier Transform Infrared Spectroscopy (Bruker Platinum ATR), UV Spectrometer (SHIMADZU Global Instruments, Japan) and Differential Scanning Colorimetry.

The tools used in making of edible films were Glass beakers, Measuring cylinder, Spatula, Stirring rods and Teflon plates.

\section{Research Method}

This is an experimental research. The research design used was completely randomized design (CRD). There were four types of treatment of different essential oil concentrations, namely $0 \%$,

Figure 1. Graphical Abstract.

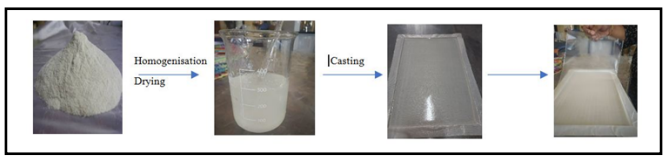

Figure 2. Methodology.

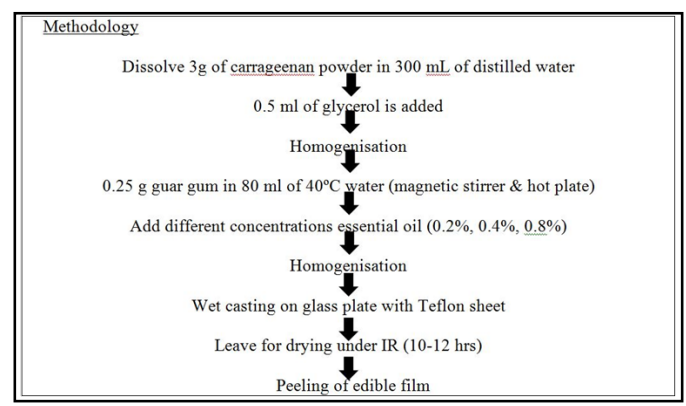

Table1. Thickness, tensile and percent elongation of edible films.

\begin{tabular}{|c|c|c|c|c|}
\hline SL.NO & CONCENTRATION & $\begin{array}{c}\text { THICKNESS } \\
(\mathbf{m m})\end{array}$ & $\begin{array}{c}\text { TENSILE } \\
\text { STRENGH (MPa) }\end{array}$ & $\begin{array}{c}\text { PERCENT ELON- } \\
\text { GATION(\%) }\end{array}$ \\
\hline 1 & $\begin{array}{c}\text { Edible film without } \\
\text { essential oil }\end{array}$ & $0.0479 \pm 0.003$ & $5.69 \pm 0.06$ & $57.81 \pm 0.08$ \\
\hline 2 & $\begin{array}{c}\text { Edible film with 0.2\% } \\
\text { essential oil }\end{array}$ & $0.0482 \pm 0.002$ & $7.12 \pm 0.04$ & $46.08 \pm 0.02$ \\
\hline 3 & $\begin{array}{c}\text { Edible film with 0.4\% } \\
\text { essential oil }\end{array}$ & $0.0486 \pm 0.005$ & $7.35 \pm 0.02$ & $18.27 \pm 0.06$ \\
\hline 4 & $\begin{array}{c}\text { Edible film with 0.6\% } \\
\text { essential oil }\end{array}$ & $0.0487 \pm 0.004$ & $7.78 \pm 0.03$ & 0.09 \\
\hline
\end{tabular}

Table 2. Colour measurement of edible films.

\begin{tabular}{|c|c|c|c|c|c|}
\hline SL NO & CONCENTRATION & $\mathbf{L}^{*}$ & $\mathbf{a}^{*}$ & $\mathbf{b}^{*}$ & $\mathbf{D E}^{*} \mathbf{a b}$ \\
\hline 1 & Target & 94.33 & 0.07 & 0.53 & ------ \\
\hline 2 & $\begin{array}{c}\text { Edible film without es- } \\
\text { sential oil }\end{array}$ & $95.48 \pm 0.04$ & $0.07 \pm 0$ & $0.58 \pm 0.02$ & $1.15 \pm 0.04$ \\
\hline 3 & $\begin{array}{c}\text { Edible film with 0.2\% film with 0.4\% } \\
\text { essential oil }\end{array}$ & $95.40 \pm 0.11$ & $0.02 \pm 0$ & $1.57 \pm 0.04$ & $1.50 \pm 0.04$ \\
\hline 4 & $\begin{array}{c}\text { Edible film with } 0.6 \% \\
\text { essential oil }\end{array}$ & $95.63 \pm 0.02$ & $0.09 \pm 0$ & $1.49 \pm 0.02$ & $1.98 \pm 0.04$ \\
\hline
\end{tabular}


Table 3. WVTR values of edible films.

\begin{tabular}{|c|c|c|}
\hline SL.NO & CONCENTRATION & WVTR $\left(\mathrm{g} / \mathrm{m}^{2} /\right.$ day $)$ \\
\hline 1 & Edible film without essential oil & $4.67 \pm 0.21$ \\
\hline 2 & $\begin{array}{c}\text { Edible film with } 0.2 \% \text { essential } \\
\text { oil }\end{array}$ & $4.62 \pm 0.13$ \\
\hline 3 & $\begin{array}{c}\text { Edible film with } 0.4 \% \text { essential } \\
\text { oil }\end{array}$ & $4.12 \pm 0.41$ \\
\hline 4 & $\begin{array}{c}\text { Edible film with } 0.6 \% \text { essential } \\
\text { oil }\end{array}$ & $4.04 \pm 0.32$ \\
\hline
\end{tabular}

Table 4. Otr values of edible films.

\begin{tabular}{|c|c|c|}
\hline SL.NO & CONCENTRATION & OTR $\left(\mathrm{cc} / \mathrm{m}^{2} /\right.$ day $)$ \\
\hline 1 & Edible film without essential oil & $2.76 \pm 0.35$ \\
\hline 2 & $\begin{array}{c}\text { Edible film with } 0.2 \% \text { essential } \\
\text { oil }\end{array}$ & $2.76 \pm 0.23$ \\
\hline 3 & $\begin{array}{c}\text { Edible film with } 0.4 \% \text { essential } \\
\text { oil }\end{array}$ & $2.74 \pm 0.43$ \\
\hline 4 & $\begin{array}{c}\text { Edible film with } 0.6 \% \text { essential } \\
\text { oil }\end{array}$ & $2.74 \pm 0.40$ \\
\hline
\end{tabular}

Table 5. Water activity of edible films.

\begin{tabular}{|c|c|c|}
\hline SL.NO & CONCENTRATION & WATER ACTIVITY (aw) \\
\hline 1 & Edible film without essential oil & $0.50 \pm 0.08$ \\
\hline 2 & $\begin{array}{c}\text { Edible film with } 0.2 \% \text { essential } \\
\text { oil }\end{array}$ & $0.49 \pm 0.01$ \\
\hline 3 & $\begin{array}{c}\text { Edible film with } 0.4 \% \text { essential } \\
\text { oil }\end{array}$ & $0.48 \pm 0.04$ \\
\hline 4 & $\begin{array}{c}\text { Edible film with } 0.6 \% \text { essential } \\
\text { oil }\end{array}$ & $0.48 \pm 0.04$ \\
\hline
\end{tabular}

$0.2 \%, 0.4 \%, 0.6 \%$ and each treatment was repeated five times $[9$, $10,13]$.

\section{Work Procedure}

Films were obtained by the Solvent casting technique.

\section{Making Of Control Edible Film}

Carrageenan solution was prepared by dissolving $3 \mathrm{~g}$ of carrageenan powder in $300 \mathrm{~mL}$ of distilled water under magnetic stirring of $800 \mathrm{rpm}$ speed at room temperature of $28^{\circ} \mathrm{C}$. Then add glycerol of $0.5 \mathrm{~mL}$ as plasticizer to the solution and continue stirring up to $30 \mathrm{~min}$ for complete dissolution. After that mix $0.25 \mathrm{~g}$ of guar gum in $80 \mathrm{~mL}$ of $40^{\circ} \mathrm{C}$ distilled water using magnetic stirrer and hot plate and dissolve this solution with the carrageenan solution. Kept it for 2-3 hours without any disturbance or in refrigerator to remove the bubbles formed in the solution. The homogenous solution without air bubbles was spread on wet casting glass plate with Teflon sheet on it for easy removal. Thus, the solution spread was allowed for air drying under IR light for 10-12 hours [15, 18, 19].

\section{Preparation Of Edible Film With Bioactive Compound}

Carrageenan solution was prepared by dissolving $3 \mathrm{~g}$ of carrageenan powder in $300 \mathrm{~mL}$ of distilled water under magnetic stirring of $800 \mathrm{rpm}$ speed at room temperature of $28^{\circ} \mathrm{C}$. Then add glycerol of $0.5 \mathrm{~mL}$ as plasticizer to the solution and continue stirring up to $30 \mathrm{~min}$ for complete dissolution. After that mix $0.25 \mathrm{~g}$ of Guar gum in $80 \mathrm{~mL}$ of $40^{\circ} \mathrm{C}$ distilled water using magnetic stirrer and hot plate and dissolve this solution with the carrageenan solution. Then lemongrass essential oil (LGO) of different concentrations like $0.2 \%(\mathrm{v} / \mathrm{v}), 0.4 \%(\mathrm{v} / \mathrm{v}), 0.6 \%(\mathrm{v} / \mathrm{v})$ are added for separate edible film solutions. Kept it for 2-3 hours without any disturbance or in refrigerator to remove the bubbles formed in the solution $[20,21,22]$. The homogenous solution without air bubbles was spread on wet casting glass plate with Teflon on it for easy removal. Thus, the solution spread was allowed for air drying under IR light for 10-12 hours.

\section{Types Of Films:}

- $\mathrm{CA}+0 \%$ LGO (CA)

- $\mathrm{CA}+0.2 \%$ LGO (CA-L0.2)

- $\mathrm{CA}+0.4 \%$ LGO (CA-L0.4)

- $\mathrm{CA}+0.6 \%$ LGO (CA-LO.6) 
Figure 3. Ftir overlay graphs of edible film with different concentrations of essential oil.

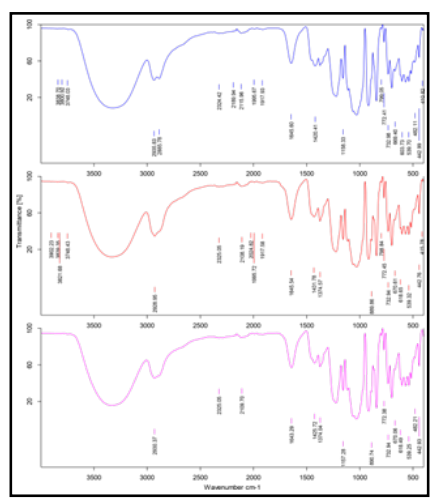

Figure 4. Sem micrograph of edible film without essential oil.

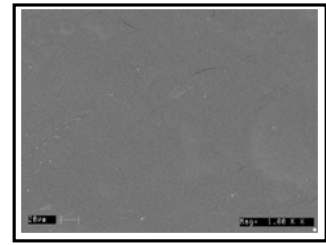

Figure 5. Sem micrograph of edible film with $0.2 \%$ essential oil.

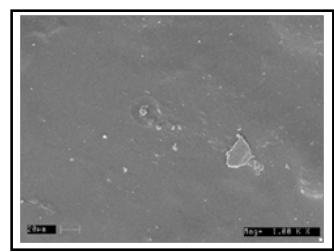

Figure 6. Sem micrograph of edible film with $0.4 \%$ essential oil.

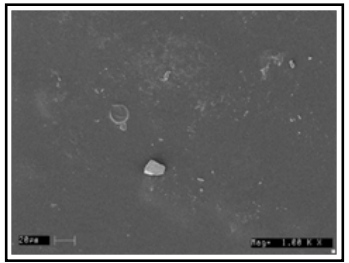

Figure 7. Sem micrograph of edible film with $0.6 \%$ essential oil.

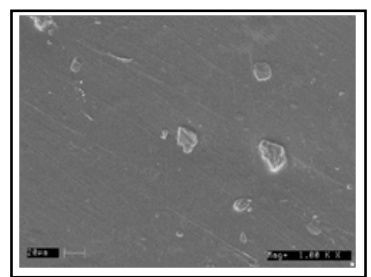

\section{Results and Discussion}

All films produced were easy to handle and transparent. They were also easily removed from the casting plate surface and had good flexibility and a smooth surface (based on visual observation).

\section{Characterization Of Film}

Thickness: The thickness of the various prepared films was measured by an electronic micrometre (Messmer instruments Ltd, England). The variations in the film are tabulated in the table. The thickness is a critical value for edible film. For this reason, the influences of lemongrass essential oil on the thickness of Carrageenan based films were initially evaluated (Table 1). Film thickness of all treatments ranged from $0.0479 \pm 0.003 \mathrm{~mm}$ to $0.0487 \pm 0.004 \mathrm{~mm}$. Table 1 shows that when the concentration of essential oil increased, the thickness of the film incorporated with essential oils also slightly increased. Therefore, it can be concluded that the variation in the reading of film thicknesses was merely affected by the ratio of the materials like essential oils used in film blending same as that of CMC and Chitosan films due to bioactive compounds [23, 26].

Tensile Strength: Measured According To ASTM D882-18: Tensile strength was studied using UTM instrument (Lloyd instruments, England) and the variation in tensile strength is tabulated 
Figure 8. Dsc analysis of edible film with $0.2 \%$ essential oil.

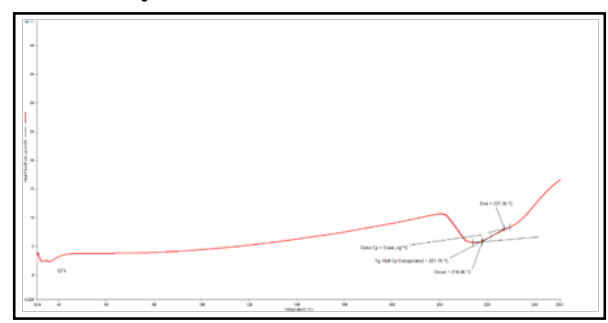

Figure 9. Dsc analysis of edible film with $0.4 \%$ essential oil.

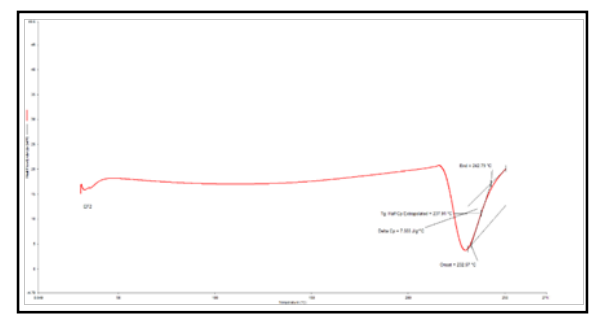

Figure 10. Dsc analysis of edible film with $0.6 \%$ essential oil.

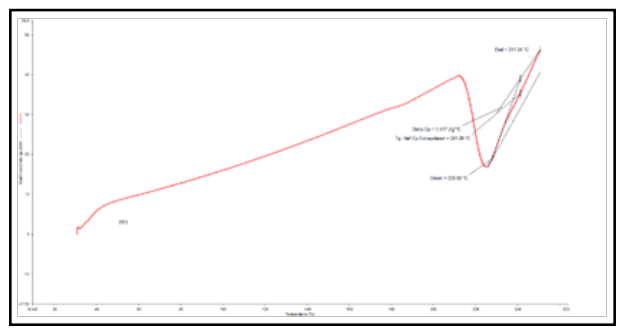

Figure 11. Lemon after 6 and 12 days of storage.

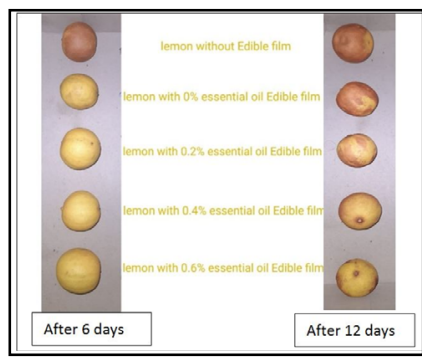

in table 1 . From the table 2 we can see that $0.6 \%$ essential oil incorporated edible films had the highest tensile strength. The lowest tensile strength was observed in the edible film without essential oil. On the comparison with the edible film without essential oil, it is seen that incorporation of essential oil have modified the resistance of the film $[24,25]$. Tensile strength of the edible film without essential oil was $5.69 \pm 0.06 \mathrm{MPa}$ increasing to the maximum 7.78 $\pm 0.03 \mathrm{MPa}$ upon addition of $0.6 \%(\mathrm{v} / \mathrm{v})$ essential oil. The tensile strength of the edible film with $0.2 \%$ was $7.12 \pm 0.04$ $\mathrm{MPa}$ and the edible film with $0.4 \%$ was $7.35 \pm 0.02 \mathrm{MPa}$. The study reveals that the increased concentration of essential oil increases the tensile strength of the film. All films with high amounts of essential oil had higher tensile strength and lower percent elongation at break. Increasing the concentration of a plasticizer (glycerol) decreased tensile strength (TS) of the film same as that of protein edible film [5]. So, in every films $0.5 \mathrm{~mL}$ plasticizer was added after trying different concentration of glycerol.

Percent Elongation: Measured According To ASTM D88218: Percent elongation was studied using UTM instrument (Llyod instruments, England) and results was tabulated in table 1. The percentage elongation has decreased according to the increase in the concentration of essential oil. The maximum percentage elongation was $57.81 \pm 0.08 \%$ showed by edible film without essential oil and the minimum percentage elongation was $18.27 \pm 0.06 \%$ showed by the edible film with $0.6 \%$. This is because the essential incorporated edible films do not possess elasticity. The use of plasticizers tends to reduce the tensile strength and increase the percentage of elongation in edible films because the plasticizers can reduce intermolecular forces and increase the mobility of biopolymer. chains. The combination of high tensile strength and high elongation leads to the material of high toughness [27, 29].

Colour Measurement: A CIE Colorimeter (Minolta colour analysis) was used to study the colour measurement of the films prepared using carrageenan, glycerol and guar gum incorporated with lemongrass essential oil at different concentrations. From the table 2 , we can see that the yellow tinge $\left(b^{*}\right)$ of the edible film is increasing according with the essential oil concentration increases because, the lemongrass essential oil is added in the edible film preparation which already have a yellow colour. Edible film without essential oil has yellow tinge $\left(b^{*}=0.58 \pm 0.02\right)$ and slight red 
tinge $\left(\mathrm{a}^{*}=0.7 \pm 0\right)$. Red tinge $\left(\mathrm{a}^{*}\right)$ of the edible film also increases with the increase in the concentration of the edible film. The edible film with $0.6 \%$ essential oil has much higher colour value when compared with others. It has brightness $\left(L^{*}\right)$ of $95.63 \pm 0.02$, red tinge $\left(a^{*}=0.09 \pm 0\right)$ of and yellow tinge $\left(b^{*}\right)$ of $1.49 \pm 0.02$.

\section{Barrier Property}

An edible film should be resistant in order to with stand manipulation during its application and to maintain its integrity and its barrier properties.

Water Vapour Transmission Rate (WVTR): Measured According To ASTM D570-18: WVTR is calculated and tabulated in the table 4 . The water vapor permeability should be as low as possible since an edible film or coating should retard moisture transfer between the food and the environment, or between two components of a heterogeneous food product [7]. WVTR value decreased with increase in the concentration of essential oil. WVTR is minimum for the edible film without essential oil and maximum for the highest essential oil concentration $(0.6 \%)$ incorporated edible film. The WVTR for the edible film with $0.6 \%$ essential oil was $4.04 \pm 0.32 \mathrm{~g} / \mathrm{m}^{2} /$ day, the edible film with $0.4 \%$ essential oil was $4.12 \pm 0.41 \mathrm{~g} / \mathrm{m}^{2} /$ day and the edible film with $0.2 \%$ was $4.62 \pm 0.13 \mathrm{~g} / \mathrm{m}^{2} /$ day. The WVTR value for the edible film with different concentrations of essential oil have much great difference. In terms of the barrier, an increase in the water molecule content will result in lower water vapour barrier properties [16].

\section{Oxygen Transmission Rate (OTR) Measured According} To ASTM D3985-17: Good oxygen barrier properties of edible films are desired in food packaging and preservation. From the table 5, we can see that edible films have low barrier property for gases. Edible film with and without essential oil have not many variations in OTR values.

Water Activity: Water activity was checked using the Novasina Lab Master aw neo instrument. It is seen that the values are lesser than the threshold level for microbial growth i.e. 0.6. there by assuring no microbial contamination under ambient conditions.

\section{Structural Properties Of Film}

Fourier Transform Infrared Spectroscopy (FTIR): Fourier transform infrared spectroscopy is a diagnostic technique used for the identification of chemical compounds. The FT-IR spectra of the edible film with essential oil $(0.2 \%, 0.4 \% \& 0.6 \%)$ are represented in the following figures:

Here, FTIR was used to study the interaction between carrageenan film matrix and lemongrass essential oil. The spectra of the edible films incorporated with different concentrations of essential oils are presented in figures respectively. All spectra show similar IR absorbance patterns. From the results, it appears that there was no structural change for each film incorporated with different concentrations of essential oils. This indicates that there was no interaction between active compounds of lemongrass oil with the functional groups of the carrageenan film. Therefore, the active compounds of lemongrass oil were free to inhibit the microorganisms. As the concentration of lemongrass oil increased, the zones of inhibition also increased significantly at all levels. However, the addition of lemongrass oil in to the film changed its mechanical properties of film by acting as a plasticizer, which improves its flexibility and extensibility. All the films showed characteristic peaks in the range of $3100-3500 \mathrm{~cm}-1$ corresponding to $\mathrm{O}-\mathrm{H}$ stretching of polysaccharide and free hydroxyl group. The absorption peaks at 2881 and $2869 \mathrm{~cm}-1$ corresponds to C-H stretching vibrations in the carrageenan polymer chain. A typical amide I peak appeared at $1637 \mathrm{~cm}-1$ in the spectra of all carrageenan-based films. The characteristic peaks at 913 and 840 cm-1 were related to C-O of 3,6-anhydro-D-galactose and C-OSO3 of D-galactose-4-sulfate, respectively. In general, the FT-IR spectra of I-carrageenan essential oil films were relatively similar and no significant changes in functional groups were observed in all the samples, indicating that the structure of the carrageenan has not been changed by essential oil. This relationship has been observed in chitosan films [2].

Scanning Electron Microscopy (SEM): The permeability of the film can be influenced by the composition, morphology and homogeneity of the coating matrix. A SEM micrograph shows a two-phase surface morphology of edible films incorporated with essential oils and the edible film without essential oil. They help us understand the molecular alignment between carrageenan and essential oil. The edible films were magnified at 500X and 1000X. The 1000X magnified micrographs are clearer than 500X. Fig 4.3.2.1 to 4.3.2.4 shows the $1000 \mathrm{X}$ magnified micrographs of edible film without essential oil and with different concentrations of essential oils. From all the micrographs it was noted that the film with essential oil shows rough, dry and uneven surface. Figure 4.3.2.1 depict surface and cross sections of the edible film without essential oil which appear to be homogeneous, smooth, and free of any dimples or crevices as previously observed for pullulan film [14].

The edible film with $0.2 \%$ essential has dimples when compared to edible film without essential oil.

films due to the higher concentration of essential oils. From the SEM micrographs we can easily differ the edible film with essential oil when comparing with edible film without essential oil.

Differential Scanning Calorimetry (DSC): The DSC analysis was done to determine the thermal properties of the films. It is imperative to determine the melting point on which the sealability of the films depends. It is measured in ${ }^{\circ} \mathrm{C}$ and denoted by $\mathrm{Tg}$. It was measured from 20 to $250^{\circ} \mathrm{C}$. Changes in the phases or state and corresponding enthalpies $(\Delta \mathrm{H})$ were determined $[1,4,6]$. It is seen that the incorporation of essential oil into edible films cause changes in the thermal properties of the films. It is known that glass transition temperature $(\mathrm{Tg})$ is a complex phenomenon depends on many factors including intermolecular interactions, the molecular weight, the chain flexibility, the branching and the molecular weight, the chain flexibility, the branching and the cross linking density [3]. Tg is increasing according to the increase in the concentration of essential oils $(0.2 \%, 0.4 \% \& 0.6 \%)$.

The glass transition temperature ( $\mathrm{Tg}$ ) of edible film with $0.2 \%$ is $221.78^{\circ} \mathrm{C}$. The end temperature is $227.36^{\circ} \mathrm{C}$ and Onset temperature is $218.00^{\circ} \mathrm{C}$.

The glass transition temperature ( $\mathrm{Tg}$ ) of edible film with $0.4 \%$ is $237.91^{\circ} \mathrm{C}$. The end temperature is $242.79^{\circ} \mathrm{C}$ and Onset temperature is $232.57^{\circ} \mathrm{C}$. 
The glass transition temperature ( $\mathrm{Tg}$ ) of edible film with $0.6 \%$ is $241.26^{\circ} \mathrm{C}$. The end temperature is $242.24^{\circ} \mathrm{C}$ and Onset temperature is $228.02^{\circ} \mathrm{C}$.

One of the important thermal properties of materials is in the packaging industry is glass transition temperature $(\mathrm{Tg})$. Modulated differential scanning calorimetry is a common method used to determine the $\mathrm{Tg}$ of biopolymeric films because of the complexity and aging of biopolymer structures. The results indicated that the glass transition temperature ( $\mathrm{Tg}$ ) of the edible film increases with increase in the concentration $(0.2 \%, 0.4 \%, 0.6 \%)$ of essential oil as that of pectin film [3].

\section{Application Of Edible Film On Lemon}

For shelf life studies lemon was taken and kept for 12 days. Fruits wrapped with $0 \%$ essential oil edible films, $0.2 \%$ essential oil edible films, $0.4 \%$ essential oil edible films, $0.6 \%$ essential oil edible film and fruits without wrapped. Two withdrawals were taken after 6 days of intervals.

Weight Loss: Weight loss was significantly lower throughout all concentrations $(0.2 \%, 0.4 \%, 0.6 \%)$ of essential oil edible films and shelf life periods when compared to unwrapped lemons (control). Weight loss increased after 6 days of storage. Edible film incorporated with essential oil application reduced the weight loss with respect to unwrapped lemons as previously observed for jack fruit [28].

Sensory Evaluation: The analysis of overall appearance conducted after storage and shelf life were rated as edible film with $0.6 \%$ essential oil is more acceptable than others according to its colour, texture, flavour, and taste. The control lemon fully turned to brown colour which is not acceptable one anymore. Lemon wrapped with edible film of different concentrations of essential oils are perfect when compared with edible film without essential oil, because the lemon wrapped edible film without the content of essential oil had colour change from yellow to brown. The smell of lemons also can retain by using the edible film with lemongrass essential oil as bioactive compound. By conducting this application of edible film, we can understand that the edible film with essential oil is effective to extend the shelf life of fruits.

\section{Conclusion}

The incorporation of bioactive compound to edible film may have additional functions in direct food packaging. The incorporation of lemongrass essential oil into carrageenan matrix was successfully performed to obtain bioactive edible films. The physical and mechanical properties of natural polymer or film made from carrageenan and glycerol was improved by the addition of lemongrass essential oil as bioactive compound. The present study indicated that, $0.6 \%$ level of essential oil was found to be most suitable for edible film preparation based on certain film characteristics like percent elongation, water vapour transmission rate, oxygen transmission rate. Overall, the incorporation of essential oil compounds in carrageenan films resulted in the decrease of the WVTR and OTR and in the increase of tensile strength were successfully related with mechanical and barrier properties. The colour change of the edible film increased according to the in- crease in concentration of lemongrass essential oil also shows the effect of essential oil on the carrageenan edible film matrix. FTIR analyses suggest different intensities of the chemical interaction occurring between functional groups of lemongrass essential oilbased bioactive compounds and active groups of carrageenan films. SEM micrographs and DSC graphs of edible film was affected by the amount of the essential oil incorporation.

For the application of edible film, lemon fruits were wrapped without and with different concentrations $(0.2 \%, 0.4 \%, 0.6 \%)$ of lemongrass essential oil incorporated edible films and lemons without edible wrap was also kept as a control for comparable studies. Lemons were kept for 6 and 12 days of shelf life study and lemons wrapped with essential oil incorporated edible film came out as an acceptable one and the control completely spoiled. The edible film without essential oil also started spoiling. Wrapping of lemon with essential oil incorporated edible film reduced the weight loss, colour change and smell of the lemon was retained. Therefore, based on the overall results, it was concluded that $0.6 \%$ lemongrass essential oil edible film had the best properties and can be considered as an effective strengthening strategy to use carrageenan based materials for food packaging applications and it could be introduced as a good alternative substance for the production of strong, completely edible and food packaging material. The microbial activity of the lemongrass oil is the reason of the increased shelf life of lemon with essential oil incorporated edible film. The application of edible film on lemon results suggest a high potential of these films to be used as active packaging materials, and further studies must be developed in order to access bioactivity and behaviour along shelf-life.

\section{References}

[1]. Astuti P, Erprihana AA. Antimicrobial edible film from banana peels as food packaging. American Journal of Oil and Chemical Technologies. 2014;2(2):66-70.

[2]. Bourtoom T. Edible films and coatings: characteristics and properties. International food research journal. 2008 Jan 1;15(3):237-48.

[3]. Chaichi M, Hashemi M, Badii F, Mohammadi A. Preparation and characterization of a novel bionanocomposite edible film based on pectin and crystalline nanocellulose. Carbohydr Polym. 2017 Feb 10;157:167-175. Pubmed PMID: 27987882.

[4]. Chakravartula SSN, Soccio M, Lotti N, Balestra F, Dalla Rosa M, Siracusa V. Characterization of Composite Edible Films Based on Pectin/Alginate/Whey Protein Concentrate. Materials (Basel). 2019 Aug 1;12(15):2454. Pubmed PMID: 31374873

[5]. Choi WS, Han JH. Physical and mechanical properties of pea-protein-based edible films. Journal of Food Science. 2001 Mar;66(2):319-22.

[6]. Erkmen O, Barazi AO. General Characteristics of Edible Films. Vol. 2 No. 1: 3 Received: January 22, 2018. Accepted: January. 2018;29.

[7]. Hafnimardiyanti H, Armin MI. Effect of plasticizer on physical and mechanical characteristics of edible film from mocaf flour. Der Phamacia Lettre. 2016;8(19):301-8.

[8]. He S, Wang Y, Sun Y, Chen S, Zhang Y, Ying M. Antimicrobial activity and preliminary characterization of K-carrageenan films containing cinnamon essential oil. Advance Journal of Food Science and Technology. 2015 Sep 5;9(7):523-8.

[9]. Kaya M, Khadem S, Cakmak YS, Mujtaba M, Ilk S, Akyuz L, et al. Antioxidative and antimicrobial edible chitosan films blended with stem, leaf and seed extracts of Pistacia terebinthus for active food packaging. RSC advances. 2018;8(8):3941-50

[10]. Khairunnisa S, Junianto J, Zahidah Z, Rostini I. The effect of glycerol concentration as a plasticizer on edible films made from alginate towards its physical characteristic. World Scientific News. 2018;112:130-41.

[11]. Lee KY, Yang HJ, Song KB. Application of a puffer fish skin gelatin film containing Moringa oleifera Lam. leaf extract to the packaging of Gouda cheese. J Food Sci Technol. 2016 Nov;53(11):3876-3883. Pubmed PMID: 28035143.

[12]. Mellinas C, Valdés A, Ramos M, Burgos N, Garrigos MD, Jiménez A. Ac- 
tive edible films: Current state and future trends. Journal of Applied Polymer Science. 2016 Jan 10;133(2).

[13]. Moosavi-Nasab M, Shad E, Ziaee E, Yousefabad SH, Golmakani MT, Azizinia M. Biodegradable Chitosan Coating Incorporated with Black Pepper Essential Oil for Shelf Life Extension of Common Carp (Cyprinus carpio) during Refrigerated Storage. J Food Prot. 2016 Jun;79(6):986-93. Pubmed PMID: 27296603.

[14]. Morsy MK. Incorporation of Essential Oils and Nanoparticles in Pullulan Films to Control Foodborne Pathogens on Meat and Poultry Products. , Journal of Food Science. 2015 Feb 9;79(1):1.

[15]. Necas J, Bartosikova L. Carrageenan: a review. Veterinarni medicina. 2013 Apr 1;58(4).

[16]. Othman SH, Edwal SA, Risyon NP, Basha RK, A TALIB R. Water sorption and water permeability properties of edible film made from potato peel waste. Food Science and Technology. 2017 Dec;37:63-70.

[17]. Otoni CG, Avena-Bustillos RJ, Azeredo HMC, Lorevice MV, Moura MR, Mattoso LHC, et al. Recent Advances on Edible Films Based on Fruits and Vegetables-A Review. Compr Rev Food Sci Food Saf. 2017 Sep;16(5):11511169. Pubmed PMID: 33371612.

[18]. Rahmawati M, Arief M, Satyantini WH. The Effect of Sorbitol Addition on the Characteristic of Carrageenan Edible Film. InIOP Conference Series: Earth and Environmental Science 2019 Feb 1 (Vol. 236, No. 1, p. 012129). IOP Publishing.

[19]. Rawdkuen S. Edible Films Incorporated with Active Compounds: Their Properties and Application. In Active Antimicrobial Food Packaging. IntechOpen. 2018.

[20]. Saleha S. Preparation and characterization edible film packaging from carrageenan. InProceedings of The Annual International Conference, Syiah Kuala University-Life Sciences \& Engineering Chapter 2013 Dec 31 (Vol. 3, No. 3).

[21]. Siracusa V, Romani S, Gigli M, Mannozzi C, Cecchini JP, Tylewicz U, et al. Characterization of Active Edible Films based on Citral Essential Oil, Alginate and Pectin. Materials (Basel). 2018 Oct 15;11(10):1980. Pubmed
PMID: 30326558.

[22]. Soni A, Gurunathan K, Mendiratta SK, Talukder S, Jaiswal RK, Sharma H. Effect of essential oils incorporated edible film on quality and storage stability of chicken patties at refrigeration temperature $\left(4 \pm 1^{\circ} \mathrm{C}\right)$. J Food Sci Technol. 2018 Sep;55(9):3538-3546. Pubmed PMID: 30150812.

[23]. Suderman N, Isa MI, Sarbon NM. Effect of drying temperature on the functional properties of biodegradable CMC-based film for potential food packaging. International Food Research Journal. 2016 Aug 1;23(3).

[24]. Supardan MD, Annisa Y, Arpi N, Satriana S, Wan Mustapha WA. Cassava starch edible film incorporated with lemongrass oil: characteristics and application. International Journal on Advanced Science, Engineering and Information Technology. 2016;6(2):216-20.

[25]. Šuput DZ, Lazić VL, Pezo LL, Popović SZ, Hromiš NM, Bulut SN. The effects of glycerol and guar-xanthan mixture on mechanical and barrier properties of starch based edible films-chemometric analysis. Hemijska industrija. 2016;70(6):739-44.

[26]. Šuput DZ, Lazić VL, Popović SZ, Hromiš NM. Edible films and coatings: Sources, properties and application. Food and Feed Research. 2015;42(1):1122.

[27]. Tahir HE, Xiaobo Z, Mahunu GK, Arslan M, Abdalhai M, Zhihua L. Recent developments in gum edible coating applications for fruits and vegetables preservation: A review. Carbohydr Polym. 2019 Nov 15;224:115141. Pubmed PMID: 31472839.

[28]. Teja TR, Santhi KK, Narsingarao A. Edible film coating of fresh cut jack fruit. Int. J. Sci., Environment and Technol. 2016;16:1658-68.

[29]. Wahyuni ES, Arifan F. Optimization of chitosan drying temperature on the quality and quantity of edible film. InE3S Web of Conferences 2018 (Vol. 31, p. 03012). EDP Sciences.

[30]. Zuhal OK, Yavuz Y, Kerse S. Edible film and coating applications in fruits and vegetables. Alınteri Zirai Bilimler Dergisi. 2018 Dec 29;33(2):221-6. 